The Journal of Animal \& Plant Sciences, 30(4): 2020, Page: 905-912

ISSN (print): 1018-7081; ISSN (online): 2309-8694

\title{
FOLIAR APPLICATION OF MICRONUTRIENTS IMPROVES GROWTH, PRODUCTIVITY AND FRUIT QUALITY OF STRAWBERRY (Fragaria ananassa Duch)
}

\author{
M. Z. Farid ${ }^{1 *}$, K. M. Qureshi ${ }^{1}$, S. H. Shah ${ }^{2 *}$, A. A. Qureshi ${ }^{1}$, M. Umair ${ }^{1}$ and H. Shafiq ${ }^{1}$ \\ ${ }^{1}$ Department of Horticulture, PMAS, Arid Agriculture University, Rawalpindi, Pakistan \\ ${ }^{2}$ Department of Agricultural Sciences, Allama Iqbal Open University, Islamabad, Pakistan \\ *Correspondence authors' e-mail: fchodaryzaki2011@gmail.com; sabir.hussain@aiou.edu.pk
}

\begin{abstract}
Strawberry is an excellent source of vitamin C, potassium, secondary metabolites, sugar and fiber, and it has delicious flavor and taste. Soil fertility is one of the most important problems in arid and semi-arid areas. Therefore, foliar nutrient supply is an effective method to fulfill plant nutrition. It provides the sufficient amount of nutrients for successful crop development in case of unavailability of plant nutrients from the soil. Therefore, this study was conducted to evaluate the influence of foliar feeding of micronutrients on vegetative, reproductive and fruit quality of strawberry $\mathrm{cv}$. Chandler. The results revealed that the maximum plant height, crown diameter, number of leaves, number of trusses, number of runners per plant and leaf area were recorded from $\mathrm{Cash}^{+} @ 3.5 \mathrm{ml} / \mathrm{l}$, while fresh weight of leaves, dry weight of leaves, fresh weight of plants, dry weight of plants and canopy size were improved by the foliar spray of Cash ${ }^{+} @ 2.5 \mathrm{ml} / 1$. Similarly, the maximum total soluble solids, ascorbic acid and titratable acidity were figured out for plants sprayed with Cash ${ }^{+} @$ $3.5 \mathrm{ml} / \mathrm{l}$. The reproductive growth of chandler was improved by the foliar spray of Libreal TMX @ $2.5 \mathrm{~g} / \mathrm{l}$. Our studies clearly indicate that foliar spray of micronutrient sources can be recommended for regulating vegetative and reproductive growth as well as fruit quality of strawberry.
\end{abstract}

Key words: Foliar application, Fruit quality, Micronutrients, Reproductive characteristics, Strawberry, Vegetative growth.

https://doi.org/10.36899/JAPS.2020.4.0106

Published online April 25, 2020

\section{INTRODUCTION}

Fruits are an important part of Pakistan's agricultural exports. The environment and soil of Pakistan is favorable for the production of fruits. Due to the favorable environment approximately 30 types of fruits are commonly produced in Pakistan (Khan et al., 2016). Strawberry (Fragaria ananassa Duch) is one of the most delicious fruit. It belongs to family Rosaceae, native to mountainous tropical and temperate regions. It is a perennial stoloniferous herb bearing red colored edible berries. Commercially grown strawberry cultivar has modern origin and hybrid between the scarlet or meadow strawberry (Fragaria viriginiana) and Chilean strawberry (Fragaria chiloensis). The hybrid Fragaria ananassa Duch not only have big size red color fruit, better aroma but also have adaptability to inconsistent environmental conditions with good resistance against pest and diseases. These overall characters of hybrid Fragaria ananassa Duch makes it most significant for commercial production all over the world (Bowling, 2000). It is one of the potential sources of vitamin C along with potassium and iron (Wang and Galletta, 2002). It has also a good portion of fiber, secondary metabolites and sugar. This helps to reduce the blood clotting problem as well as decrease the cardiovascular diseases. Strawberry is a highly nutritious fruit. It contains approximately 45 calories in a serving cup (144 g) and provides $20 \mathrm{mg}$ calcium, $240 \mathrm{mg}$ potassium and 27 $\mathrm{mg}$ phosphorous to the body. Bio-chemical analysis reveals that its pulp $(100 \mathrm{~g})$ contains $89 \mathrm{~g}$ of water, $8.4 \mathrm{~g}$ of carbohydrates, $0.5 \mathrm{~g}$ of fats and $0.07 \mathrm{~g}$ of protein along with $59 \mathrm{mg}$ ascorbic acid (Galletta and Bringhurst, 1995). Strawberries as compared with other berries have more phenolics and flavonoids (Hakkinen and Torronen, 2000). Strawberry is one the gift of nature which gives profitable returns when grown in various soil types of the country. It requires low chilling for propagation thus, the growers of highlands like Charsadda, Mardan, Mangora and Swat are producing runner and earn valuable profits, as these are the only areas which have potential to produce and supply strawberry transplants/runners all over the country. Strawberry is cultivated in spring season. Fruit attain maturity during early summer and fetch handsome revenue due to unavailability of other fruits in the market at that time. Strawberry getting popularity among farming community and a demanding enterprise due to its high return (Asad, 1997). Chandler is a seasonal fruit variety of strawberry which produces single crop in summer (Qureshi et al., 2013).

In Pakistan arid and semi-arid areas, soils are less fertile and low in essential nutrients along with poor amount of organic matter (Sarwar et al., 2008). This condition creates many problems, like nutrient and 
organic matter deficiency and moisture stress (Ugboh and Ulebor, 2011). Farmers apply chemical fertilizers to increase crop efficiency (Bengt and Martensoon, 2003). Prevailing dry environmental conditions leads the Pakistani soil towards lower in organic matter. Plants require seven essential micronutrients other than macronutrients which are zinc, boron, copper, manganese, iron, chlorine and molybdenum. Conventionally farmer use only macronutrient, which leads to many problems. Deficiency of micronutrient can be overawed by foliar and basal use of these nutrients. Knowing the factor that affect the availability of nutrient and their uptake can boost the yield. Climate, soil physical, chemical properties, plant genotypes and cultural practices affect nutrient uptake from soil (Arevalo-Gardini et al., 2015). Foliar addition of nutrient is better way to meet the plant nutrition requirement. It facilitates efficient nutrient absorption through leaves by plants. Foliar application promotes the transference of micronutrients and their availability with in plant. It can provide required quantity of nutrients for plant development where uptake and availability of these nutrients through roots from soil is inaccessible. Moreover, nutrient absorption through plant foliage is a quick way as compared to soil nutrition (Kerin and Berova, 2003).

Foliar use of nutrient is safer ecologically than the soil incorporation (Alshaal and El-Ramady, 2017). Foliar feeding can alter basal application of nutrients. Many short-season crops need highly efficient nutrient supply. Foliar applications of nutrients can rapidly overcome physiological disorders. Most of the physiological disorders are result of nutritional deficiency and stress conditions. Foliar sprays of these nutrients led to plant progress, so this method is more valuable as well as economically effective in comparison with other means of enhancing plant growth. The absorption of these nutrients though plant leaf surface is more effective than that of basel application. These nutrients can be used as foliar at any stage of plant growth and in any quantity as per crop need (Yaseen and Ahmad, 2010).

There is exigency to enhance the production of quality fruit of strawberry using cost effective nutrient management. Therefore, this study was aimed to explore the impact of micronutrient foliar application from variable sources on vegetative and reproductive attributes of strawberry. This study was designed to optimize the micro-nutritional requirements of strawberry to secure potential yield of strawberry fruits on a larger area of farmers' field.

\section{MATERIALS AND METHODS}

The research work was carried out at Pir Mehr Ali Shah Arid Agriculture University, Rawalpindi (PMAS-AAUR) during 2013-14. Transplants of
Strawberry cv. Chandler's were obtained from Swat valley and planted in $12^{\text {th }}$ October, 2013 on growth media having soil, sand and FYM in 1: 1: 1. The clay pots (I L) holding three liter media were used for experiments in greenhouse. Seven treatments were applied to observe the impact of micronutrient foliar application from variable sources on vegetative and reproductive attributes of strawberry (Table $1 \& 2$ ).

Vegetative growth parameters: Plant height was measured 60 days after transplanting (DAT) from the ground level of crown to the tip of photosynthetic tissue in centimeters using scale. Crown is the modified stem of strawberry plant from where flower clusters, leaves and runners originate. Crown diameter was estimated by the use of Vernier's caliper. Average was calculated by measuring five randomly chosen plants. Number of leaves per plant and number of trusses in each plant was counted manually and average of five plants was recorded in each replication. Runner produced by each plant was also calculated after last harvesting and averaged by five plants per replicate. Leaf area was averaged from twenty plants in each replication by using Leaf Area Meter. Fresh and dry weight was recorded and averaged from twenty plants in each replication by Weighing balance (Setra BL- 410 S) Dry weight was taken after oven drying of leaves. Similarly, fresh weight of randomly selected five plants per replication was measured using weighing balance. Same selected plants oven-dried and then their dry weight was recorded. Plant spread (canopy size) was measured in centimeters using graduated scale.

Reproductive growth parameters: All the fruits in each treatment were counted manually for precise data recording 90 DAT. Data of fruit size was measured in centimeters by using digital vernier's caliper. Fruit weight was determined by digital weighing balance and expressed in grams. Five randomly selected plants in each replication were taken and their average was recorded. Number of fruit set was counted and then recorded in percentage using following formula:

Total number of fruit set

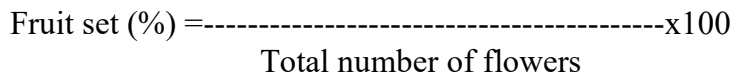

Fruit quality parameters: Total soluble solids contents in fruit were analyzed by Hand refractometer and averaged from five fruits in each replication. These total soluble solids (TSS) contents were analyzed at room temperature by following the method mentioned by AOAC (1990). Ascorbic acid contents were determined from randomly selected five fruits per replication using spectrophotometer (OPTIMA, SP-3000-plus). Fruit pulp from selected plants was mixed with $5 \mathrm{ml}$ of $0.1 \%$ hydrochloric acid. This mixture was subjected to centrifugation process for ten minutes at $10,000 \mathrm{rpm}$ 
speed. The absorbance at 243 nanometer wavelength was documented. Titratable acidity recorded through titration method at fruit ripening stage (Hans, 1992) using the following formula:

Titratable acidity $(\%)=[(\mathrm{m} \times 0.064) / 10] \times 100$ In the above formula $\mathrm{m}$ denotes Burette reading

Statistical analysis: The experiment was performed in the layout of completely randomized design (CRD). The significant difference was calculated employing analysis of variance (ANOVA) and statistical lettering was done using Least Significant Difference (LSD) system of comparison at 5\% probability level (Steel et al., 1997). MSTATC software was used for data analysis.

\section{RESULTS}

Micronutrients foliar application improves strawberry vegetative growth: The foliar application of micronutrients had a significant $(\mathrm{p}<0.05)$ effect on plant height of Fragaria ananassa (Table 3). Maximum plant height $(18.7 \mathrm{~cm})$ was recorded at $\mathrm{T}_{7}$, while minimum height $(14.6 \mathrm{~cm})$ was noticed at control. Similarly, a significant difference was found among treatments for crown diameter (Table 3). Maximum crown diameter $(12.7 \mathrm{~cm})$ was recorded at $\mathrm{T}_{7}\left(\mathrm{Cash}^{+} @ 3.5 \mathrm{ml} / \mathrm{l}\right)$ followed by T4 (Librel TMX@2.5 g/l) and T (Cash $^{+} @ 1.5$ ml/l). Data concerning number of leaves on single plant of Fragaria ananassa is shown in Table 3. Maximum number of leaves (11.0) was noted in $\mathrm{T}_{7}\left(\mathrm{Cash}^{+} @ 3.5\right.$ $\mathrm{ml} / \mathrm{l}$ ), while least number of leaves (4.7) was obtained at control (Table 3). The data showed an increase with respect to different levels of micronutrients on number of trusses (Table 3). This increase was more pronounced in plants treated with Librel TMX @ 2.5 g/l. Maximum number of trusses (6.20) was recorded at $\mathrm{T}_{4}$, while minimum number of trusses (1.93) was noticed in untreated plants (Table 3). The data about the number of runners as affected by different treatments of micronutrients have been shown in Table 3 . The results on number of runners evidently showed that application of micronutrient significantly enhanced strawberry plants runners related to control. Maximum number of runners (3.9) was attained by $\mathrm{T}_{7}\left(\mathrm{Cash}^{+} @ 3.5 \mathrm{ml} / \mathrm{l}\right)$ and minimum number (1.5) was observed in case of control plants. Level of micronutrient increase the number of runners obtained from the strawberry plant (Table 3 ). In case of leaf area same trend was observed. This increment was more in plants that were treated with $\mathrm{Cash}^{+} @ 3.5 \mathrm{ml} / \mathrm{l}$. Maximum leaf area $\left(68.6 \mathrm{~cm}^{2}\right)$ in experimental plants were attained by the effect of $\mathrm{T}_{7}\left(\mathrm{Cash}^{+} @ 3.5 \mathrm{ml} / \mathrm{l}\right)$, while strawberry plants without any micronutrient treatment attained least leaf area $\left(26.9 \mathrm{~cm}^{2}\right)$. The foliar application of micronutrients significantly increased fresh and dry weight of plants $(\mathrm{p}<0.05)$. The highest fresh biomass of strawberry foliage was enhanced in those plants that were sprayed with $\mathrm{Cash}^{+}$@ $2.5 \mathrm{ml} / \mathrm{l}$. Same results were recorded for dry biomass, which were comparable to fresh weight of leaves, dry weight of leaves, fresh weight of plants and dry weight of plants at control (Table 3). Maximum canopy size $(27.7 \mathrm{~cm})$ was recorded at $\mathrm{T}_{4}$ (Librel TMX @ $2.5 \mathrm{~g} / \mathrm{l}$ ) followed by canopy size $(24.7 \mathrm{~cm})$ achieved at $\mathrm{T}_{7}\left(\mathrm{Cash}^{+} @ 3.5 \mathrm{ml} / \mathrm{l}\right)$, while minimum canopy size $(12.3 \mathrm{~cm})$ was noticed at control in strawberry plants.

Micronutrients foliar application improves strawberry reproductive growth: The data divulged highly momentous effects $(\mathrm{p}<0.05)$ on reproductive growth of strawberry plant by the application of foliar micronutrients application. Number of days to start blooming is an important reproductive parameter. Least number of days for flowering (77) was recorded in $\mathrm{T}_{4}$ (Librel TMX@2.5 g /l). On the other hand, the maximum counted days for flowering (106.3) were recorded at control (Table 4). The data about the number of flowers per plant have been shown in Table 4 that demonstrated that the treatments varied significantly with each other. Highest counted flowers (20) was noted at $\mathrm{T}_{4}$ (Librel TMX @ 2.5 g/l) which was significantly comparable to number of flowers (6) obtained at control (Table 4). Among various treatments of foliar spray of micronutrients, T4 (Librel TMX @ $2.5 \mathrm{~g} / \mathrm{l}$ ) yielded the highest number of fruit set (17.7) followed by the number of fruit set (16.0) secured at $\mathrm{T}_{3}$ (Librel TMX @ $1.5 \mathrm{~g} / \mathrm{l}$ ) (Table 4). The least count of fruit set (3.3) was recorded in untreated control plants (Table 4). Genetic makeup of plants along with geographic location of field and pollinator's availability directly affect the fruit set percentage. Maximum fruit set percentage ( 90.7 percent) was noted in $\mathrm{T}_{4}$ (Librel TMX @ $2.5 \mathrm{~g} / \mathrm{l}$ ) treated strawberry plants, while lowest fruit set percentage (54.9 percent) was counted in control (Table 4). The results about total number of fruit per plant have been given in Table 4 that showed that treatments diverse significantly. Librel TMX@2.5 g/l ( $\left.\mathrm{T}_{4}\right)$ exhibit maximum effect for total number of fruits (18.3) followed by Librel TMX @ $1.5 \mathrm{~g} / 1\left(\mathrm{~T}_{3}\right)$ and $\mathrm{Cash}^{+} @ 3.5 \mathrm{ml} / 1\left(\mathrm{~T}_{7}\right)$ which gave an average of 13 fruits per plant. On the other hand, the lowest number of total fruits per plant (6.7) was obtained at control (Table 4). Statistical analysis clarified remarkable difference $(\mathrm{p}<0.05)$ among the treatments on fruit size. The maximum fruit size $(3.27 \mathrm{~cm})$ of treated strawberry plants was observed in $T_{4}$ and smallest fruit size was recorded in control plant $(2.51 \mathrm{~cm})$. Data regarding fruit weight (Table 4) exhibited the highest fruit weight $(18.1 \mathrm{~g})$ was recorded at $\mathrm{T}_{4}$ (Librel TMX @ $2.5 \mathrm{~g} / \mathrm{l})$ followed by $\mathrm{T}_{6}$ that yielded $15.5 \mathrm{~g}$ fruit weight that were comparable to control.

Micronutrients foliar application improves strawberry fruit quality: Statistical analysis of data on total soluble solids (TSS) showed the significant effects 
$(\mathrm{p}<0.05)$ among the treatments (Table 5). Total soluble solids (TSS) in fruits juice of strawberry was measured $7.7{ }^{0}$ Brix in $\mathrm{T}_{7}$ followed by $\mathrm{T}_{6}\left(7 . \mathrm{C}^{0} \mathrm{Brix}\right)$ that were comparable to total soluble solids $\left(5.0{ }^{0} \mathrm{Brix}\right)$ obtained at control (Table 5). Many biological processes in plants and in humans are closely influenced by a growth regulating factor known as Ascorbic acid or Vitamin C. It is water soluble and acting as an antioxidant in human body. Strawberry contains rich sources of antioxidants and valuable phenolic compounds. It has more ascorbic acid than that of oranges (Ayub et al., 2010). Statistically significant $(p<0.05)$ results were observed among different treatments in case of ascorbic acid (Table 5). Maximum value of ascorbic acid contents $(77.6 \mathrm{mg} / 100 \mathrm{~g}$ pulp) were recorded at $\mathrm{T}_{7}$ (Librel TMX@3.5 g/l), while minimum ascorbic acid contents $(32.7 \mathrm{mg} / 100 \mathrm{~g}$ pulp) were found at control. Different treatments of micronutrients had significant effect on fruit juice titratable acidity (Table 5). Maximum titratable acidity $(0.97 \%)$ was documented at $\mathrm{T}_{7}$ followed by $\mathrm{T}_{6}$ whereas control secured minimum titratable acidity $(0.22 \%)$ value (Table 5).
Table 1. Micronutrients sources and concentrations used in present study for their assessment on vegetative, reproductive as well as fruit quality of strawberry.

\begin{tabular}{lcc}
\hline Brand name & Composition & Concentrations \\
\hline Librel TMX & Boron $(\mathrm{B})$ & $10 \mathrm{~g} / \mathrm{kg}$ \\
& Copper $(\mathrm{Cu})$ & $10 \mathrm{~g} / \mathrm{kg}$ \\
& Iron $(\mathrm{Fe})$ & $30 \mathrm{~g} / \mathrm{kg}$ \\
& Manganese $(\mathrm{Mn})$ & $10 \mathrm{~g} / \mathrm{kg}$ \\
& Zinc $(\mathrm{Zn})$ & $40 \mathrm{~g} / \mathrm{kg}$ \\
\hline Cash+ & Zinc $(\mathrm{Zn})$ & $40 \mathrm{~g} / \mathrm{kg}$ \\
& Copper $(\mathrm{Cu})$ & $30 \mathrm{~g} / \mathrm{kg}$ \\
& Manganese $(\mathrm{Mn})$ & $2 \mathrm{~g} / \mathrm{kg}$ \\
& Iron $(\mathrm{Fe})$ & $1 \mathrm{~g} / \mathrm{kg}$ \\
\hline
\end{tabular}

Table 2. Seven different treatments of micronutrients used in the present study.

\begin{tabular}{ccc}
\hline Treatments & Micronutrients & Concentrations \\
\hline $\mathrm{T}_{1}$ & Simple water & \\
$\mathrm{T}_{2}$ & Librel TMX & $0.5 \mathrm{~g} / 1$ \\
$\mathrm{~T}_{3}$ & Librel TMX & $1.5 \mathrm{~g} / 1$ \\
$\mathrm{~T}_{4}$ & Librel TMX & $2.5 \mathrm{~g} / 1$ \\
$\mathrm{~T}_{5}$ & Cash $^{+}$ & $1.5 \mathrm{ml} / 1$ \\
$\mathrm{~T}_{6}$ & Cash $^{+}$ & $2.5 \mathrm{ml} / 1$ \\
$\mathrm{~T}_{7}$ & Cash $^{+}$ & $3.5 \mathrm{ml} / 1$ \\
\hline
\end{tabular}

Table 3. Effect of foliar application of micronutrients on vegetative growth of strawberry.

\begin{tabular}{|c|c|c|c|c|c|c|c|c|c|c|c|}
\hline Treatments & $\begin{array}{c}\text { Plant } \\
\text { height } \\
(\mathrm{cm})\end{array}$ & $\begin{array}{c}\text { Crown } \\
\text { diameter } \\
(\mathrm{cm})\end{array}$ & $\begin{array}{l}\text { No. of } \\
\text { leaves }\end{array}$ & $\begin{array}{c}\text { No. of } \\
\text { trusses } \\
\text { per } \\
\text { plant }\end{array}$ & $\begin{array}{c}\text { No. of } \\
\text { runners } \\
\text { per } \\
\text { plant }\end{array}$ & $\begin{array}{l}\text { Leaf } \\
\text { area } \\
\left(\mathrm{cm}^{2}\right)\end{array}$ & $\begin{array}{c}\text { Fresh } \\
\text { weight } \\
\text { of } \\
\text { leaves } \\
\text { (g) }\end{array}$ & $\begin{array}{c}\text { Dry } \\
\text { weight } \\
\text { of } \\
\text { leaves } \\
\text { (g) }\end{array}$ & $\begin{array}{l}\text { Fresh } \\
\text { weight } \\
\text { of } \\
\text { plants } \\
\text { (g) }\end{array}$ & $\begin{array}{c}\text { Dry } \\
\text { weight } \\
\text { of } \\
\text { plants } \\
\text { (g) }\end{array}$ & $\begin{array}{c}\text { Canopy } \\
\text { size } \\
(\mathrm{cm})\end{array}$ \\
\hline $\mathrm{T}_{1}$ & 14.6 & 9.4 & 4.7 & 1.9 & 1.5 & 26.9 & 1.0 & 0.18 & 10.9 & 6.1 & 12.3 \\
\hline $\mathrm{T}_{2}$ & 16.7 & 10.6 & 7.0 & 4.7 & 1.7 & 42.3 & 1.3 & 0.22 & 19.7 & 10.9 & 15.6 \\
\hline $\mathrm{T}_{3}$ & 16.9 & 11.0 & 8.4 & 5.1 & 2.3 & 57.1 & 1.4 & 0.23 & 21.9 & 11.8 & 23.2 \\
\hline $\mathrm{T}_{4}$ & 17.1 & 12.2 & 8.7 & 6.2 & 3.3 & 68.6 & 1.7 & 0.3 & 22 & 12.6 & 27.7 \\
\hline $\mathrm{T}_{5}$ & 17.6 & 11.9 & 10.9 & 4.7 & 2.6 & 57.7 & 1.8 & 0.34 & 22.3 & 13.1 & 24.7 \\
\hline $\mathrm{T}_{6}$ & 18.7 & 12.7 & 11.0 & 4.9 & 3.9 & 61.7 & 1.9 & 0.42 & 27.1 & 15.9 & 23.6 \\
\hline $\mathrm{T}_{7}$ & 16.4 & 11.1 & 8.3 & 4.0 & 2.7 & 38.7 & 1.3 & 0.32 & 21 & 10.9 & 21.7 \\
\hline
\end{tabular}

Table 4. Effect of foliar application of micronutrients on reproductive growth of strawberry.

\begin{tabular}{|c|c|c|c|c|c|c|c|}
\hline Treatments & $\begin{array}{c}\text { No. of } \\
\text { days to } \\
\text { flower }\end{array}$ & $\begin{array}{c}\text { No. of } \\
\text { flowers per } \\
\text { plant }\end{array}$ & $\begin{array}{c}\text { No. of } \\
\text { fruit set }\end{array}$ & $\begin{array}{c}\text { Fruit set } \\
\text { percentage }(\%)\end{array}$ & $\begin{array}{c}\text { Total number } \\
\text { of fruit }\end{array}$ & $\begin{array}{l}\text { Fruit size } \\
\quad(\mathrm{cm})\end{array}$ & $\begin{array}{c}\text { Fresh } \\
\text { weight (g) }\end{array}$ \\
\hline $\mathrm{T}_{1}$ & 106.3 & 6 & 3.3 & 54.9 & 2.7 & 2.51 & 8.1 \\
\hline $\mathrm{T}_{2}$ & 78 & 12.7 & 9 & 71.8 & 7.9 & 2.92 & 11.4 \\
\hline $\mathrm{T}_{3}$ & 93 & 17.7 & 16 & 84.8 & 13.7 & 3.13 & 14.1 \\
\hline $\mathrm{T}_{4}$ & 77 & 20 & 17.7 & 90.7 & 14.7 & 3.27 & 15.6 \\
\hline $\mathrm{T}_{5}$ & 84 & 11.3 & 9.7 & 82.9 & 8.3 & 3.01 & 18.1 \\
\hline $\mathrm{T}_{6}$ & 83.7 & 16.3 & 14 & 85.7 & 11.3 & 3.22 & 12.4 \\
\hline $\mathrm{T}_{7}$ & 94.7 & 11.7 & 9.3 & 82.3 & 7.7 & 2.84 & 9.5 \\
\hline
\end{tabular}


Table 5. Effect of foliar application of micronutrients on fruit quality parameters of strawberry.

\begin{tabular}{lccc}
\hline Treatments & $\begin{array}{c}\text { Total } \\
\text { soluble } \\
\text { solids } \\
\left({ }^{\mathbf{0} B r i x)}\right.\end{array}$ & $\begin{array}{c}\text { Ascorbic acid } \\
\text { (mg/100g } \\
\text { pulp) }\end{array}$ & $\begin{array}{c}\text { Titratable } \\
\text { acidity } \\
\mathbf{( \% )}\end{array}$ \\
\hline $\mathrm{T}_{1}$ & 5 & 32.7 & 0.97 \\
$\mathrm{~T}_{2}$ & 5.8 & 68.3 & 0.84 \\
$\mathrm{~T}_{3}$ & 7.1 & 75.7 & 0.55 \\
$\mathrm{~T}_{4}$ & 7.7 & 77.6 & 0.22 \\
$\mathrm{~T}_{5}$ & 5.9 & 64 & 0.64 \\
$\mathrm{~T}_{6}$ & 6.3 & 65 & 0.59 \\
$\mathrm{~T}_{7}$ & 5.8 & 43 & 0.85 \\
\hline
\end{tabular}

\section{DISCUSSION}

Strawberry (Fragaria ananassa Duch) is one of the potential sources of vitamin $\mathrm{C}$ and has highly desirable taste, flavor, potassium, fiber, secondary metabolites and sugar. It helps in reduction of blood clotting problem and heart diseases. Soil media of arid and semi-arid regions are poor in nutrients with deprived physiochemical and biological properties (Sarwar et al., 2008; Ugboh and Ulebor, 2011). Crops productivity is usually boosted by the application of chemical nutrients (Bengt and Martensoon, 2003). Plants require seven essential micronutrients other than macronutrients which are zinc, boron, copper, manganese, iron, chlorine and molybdenum. Conventionally farmer use only macronutrient, which leads to many problems. Visual and hidden micronutrient deficiencies symptoms can be cured by the appropriate use of foliar and basel application of these nutrients. Foliar use of nutrient is safer ecologically than that of the soil incorporation (Alshaal and ElRamady, 2017). Foliar applications of nutrients can rapidly overcome physiological disorders. Most of the physiological disorders are result of nutritional deficiency and stress conditions. The absorption of these nutrients though plant leaf surface is more effective than that of basal application. These nutrients can be used as foliar at any stage of plant growth and in any quantity as per crop need (Yaseen and Ahmad, 2010).

During this study, various levels of micronutrients were applied as a foliar spray and it was found that the vegetative growth of strawberry was highly boosted up with their foliar application. Our findings are in accordance with Chaturvedi et al. ( 2005) who conducted research on strawberry cv. "Chandler" and reported that plant height was increased by the application of $\mathrm{ZnSO}_{4}(0.4 \%)$ and $\mathrm{FeSO}_{4}(0.2 \%)$. Similar nature of study was reported by Kumar et al. (2012) in which they assessed bio-fertilizers and micronutrients on vegetative growth, flowers initiations and fruit yield of strawberry cv. Chandler. They were in argument that increased plant height was outcome of the micronutrients and bio-fertilizers application. It is a common observation that vegetative attributes enhanced in fruit crops including strawberry when micronutrient applied by foliar application (Bakshi et al., 2013). Development of a standard nutritional plan needs to understand climate, media and cultural practices required for strawberry quality production and their role on plant physiology. Each one has its specific role on plant growth and development (May and Pritts, 1990). Kumar et al. (2012) concluded that plants of strawberry treated with high dose of zinc led towards high crown diameter along with proliferation of secondary crowns. Our findings were also in agreement with the earlier report by Mohamed et al. (2011) who inferred that precocious amount of phosphorous and Zinc, and also their synergism improved vegetative growth, fruit quality as well as yield of strawberry. Our findings revealed that use of micronutrients substantially increased vegetative growth i.e. number of leaves per plant. Our findings are also parallel with the results of Kumar et al. (2012). The present study suggested that physiological behavior of strawberry is highly influenced by micronutrients. In the same way, rise in the flower cluster on plant was recorded by the application of micronutrients (Mohamed et al., 2011). Chaturvedi et al. (2005) reported that numbers of runners of strawberry plants were enhanced by applying $0.4 \% \mathrm{ZnSO}_{4}$. Results of this study was matched with previous report by Mohamed et al. (2011), who observed number of leaves, runners and secondary crowns count on single plant of strawberry boosted with foliar application of phosphorous and Zinc combinations. In a previous research study, Bakshi et al. (2013) demonstrated that zinc, iron and calcium application prior to flower initiation of strawberry plant boosted vegetative growth which ultimately enhanced quality and shelf life in cv. "Chandler". This research group also inferred that $0.6 \% \mathrm{FeSO}_{4}$ exhibited maximum leaf area $\left(64.74 \mathrm{~cm}^{2}\right)$. Our findings were also consonant with earlier research outcomes of Yadav et al. (2013), who conducted research in banana and reported that foliar application of micronutrients enhanced leaf area of banana plants. Similarly, El-Badawy (2013) conducted a research study in apricot and reported that vegetative growth, mineral contents and yield as well as fruit quality was significantly enhanced by the foliar of application of micronutrients. In horticultural crops, sensible plant nutrition can be attained through foliar fertilization (Fageria et al., 2009). Outcomes of these experimental studies revealed that fresh biomass of strawberry plants was expressively increased by the use of micronutrients through foliar application. Kumar et al. (2012) documented a rise in plant height, canopy spread, leaves on single plant and weight of leaves in result of bio fertilizes along with micronutrients application. Previous report of Shiriyan et al. (2013), on use of zinc and iron 
exhibited positive results of these nutrients on plant density and leaves dry weight in savory herb. During our investigations, vegetative attribute of strawberry plants were enhanced by using foliar application of micronutrients. This application increased the leaf area and fresh weight of plants (Mohamed et al., 2011). Our findings about higher fresh weight are supported by the results of Khalid (2012), who worked on coriander and sweet fennel. The findings were also concomitant with Mohamed et al. (2011). Who concluded that higher ratio of foliar application of micronutrient increased vegetative and reproductive parameters. Foliar application of micronutrients on strawberry plants influenced vegetative attributes (Chaturvedi et al., 2005). Results of this experiment coincided with previous outcome of Bakshi et al. (2013) who documented that Zinc sulphate (6\%) increased plant canopy $(31.1 \mathrm{~cm})$ in their experiment.

Sudden changes in global climate are affecting the flowering time of horticultural crops worldwide. Many researchers revealed the earliness of flowering in a wide range of crops. These effects may be specific to some species but most of the plants rely on locality and changes in climate. In a previous research article, boron when applied to plant in good amount facilitated the uptake of macronutrient especially phosphorous in tomato. It is also observed that it stimulated reproductive trait and enhanced flower development and fruit setting (Day, 2000). Foilarly applied micronutrient not only produced early flowering but enhanced number of flower on strawberry plant (Mohamed et al., 2011). The outcome of this research had uniformity with the conclusions of Mohamed et al. (2011); Kumar et al. (2012) in count of flowering per plant by the usage of micronutrients and bio-fertilizers in combination. Micronutrients act as catalysts for organic reactions occurring in plants thereby they are vital for plant growth, while their deficiencies limit the productivity of fruit crops (Singh et al., 2015). Our results revealed that the highest fruit set percentage was recorded in plants that were sprayed with Librel TMX @ $2.5 \mathrm{~g} / 1$. Control plants was observed with minimum fruit set percentage. These results were at par with Bakshi et al. (2013), concluded that number of fruit set enhanced when micronutrient were applied in foliar form. Fruit set percentage and over all fruit yield were positively enhanced by the foiler use of boron (B) in different fruits (Dale and Krystyna, 1998). Singh et al. (2015) conducted a research study on vegetative and reproductive growth of strawberry by the foliar application of iron and zinc and found a remarkable increase in fruit set percentage applying FeSO4 (0.2\%) and $\mathrm{ZnSO} 4(0.3 \%)$ as a foliar spray. Moreover, they were in argument that foliar application of micronutrients played crucial role in vegetative growth of plants signifying their involvement in photosynthesis, respiration and other physiological and biochemical characteristics. Similarly, a significant increase in inflorescence and fruit size was obtained by the application of $\mathrm{ZnSO} 4$ (Abdollahi et al., 2012). Boost in fruit setting is directly correlates with yield. Chaturvedi $e t$ al., (2005) also reported significant improvement in fruit setting percentage. Results of Dixit et al. (2013) are also aligned with the findings of this experiment. They conducted a research study in Litchi chinensi and found efficient fruit set percentage after foliar application of micronutrients. Micronutrients are popular for their role in increasing plant yield (Rehm and Sims, 2006). Higher count of total fruit on single plant was documented by Mohsen (2013) in tomatoes by the usage of micronutrients through foliar dose. Similar outcomes were mentioned by Bakshi et al. (2013) who reported efficient number of fruit per plant applying calcium, iron and zinc in combinations. Increased yield with good individual fruit weight were achieved in mango by the application of micronutrients (Bhatt et al., 2012). The outcomes of this study are parallel to the conclusions of Mohamed et al. (2011), who recommended that increase in fruit size could be achieved by the spraying of Zinc and phosphorus in a combination after flower initiation. Davis et al. (2003) revealed similar outcomes about fruit size boosted through the foliar application of boron in tomato. Yield attributes can be easily estimated by average fruit weight. Increase in total yield is directly depending upon average fruit weight. Any treatment which is boosting the fruit weigh ultimately increases the total product outcome from the field. Substantial rise in average weight of fruit was documented when applied Zinc and Iron Sulphate in combination by Chaturvedi et al. (2005). Results of this study was also supported by Bhatt et al. (2012), who found significant increase in fruit weight by foliar application of micronutrients.

High level of micronutrients spray increased TSS as compared to low levels in strawberry fruit (Perez et al., 1997). Usha and Singh (2002) explored quality attribute of 'Perlette' grapes as influenced by the application of magnesium, boron and iron in combination and found significant results. Results of this study coincided with the previous research reports by Mohamed et al. (2011); Bakshi et al. (2013). Who reported high level of micronutrient enhanced vegetative and reproductive attribute of strawberry especially TSS in fruit. Our results were also consistent with that of Bhatt $e t$ al. (2012) who conducted research on mango and ascertained that foliar spray of micronutrients improved quality of mango by increment of total soluble solids. Finding of this experiment also revealed the positive influence of micronutrient on ascorbic acid contents (vitamin C). These results are in consistent with other researchers (Bakshi et al., 2013) who worked on strawberry and found increment in ascorbic acid contents by the foliar application of micronutrients. Similar results were reported by Usha and Singh (2002) who studied the effect of micronutrients application in grapes and 
concluded that micronutrients had significant effect on ascorbic acid contents of grapes. Titratable acidity is one of the most important fruit quality attributes and is directly related with the levels of organic acids present in the fruits. It was perceived that titratable acidity at the time of ripening decreases so variations occurred between treatments. Our findings were insistent with those of Bakshi et al. (2013) who reported that pre-harvest spray of micronutrients resulted in the lowest acidity and higher total soluble solids contents. These variations might be due to different levels of micronutrients tested, environmental conditions and genotypes.

Conclusion: It is concluded that strawberry plants responded positively to foliar feeding of micronutrients. $\mathrm{Cash}^{+} @ 2.5 \mathrm{ml} / \mathrm{l}$ and $\mathrm{Cash}^{+} @ 3.5 \mathrm{ml} / \mathrm{l}$ resulted in considerable increase in vegetative growth, flower stimulation, number of leaves production, increase in foliage fresh and dry mass, while Librel TMX @ $2.5 \mathrm{~g} / 1$ provided significant increase in number of flowers, number of fruit set, fruit set percentage, total number of fruits, fruit size and fruit weight as well as quality attributes of strawberry.

Acknowledgements: The authors are highly grateful to Dr. Muhammad Sudheer Tariq, Principal Scientific Officer/Director Fruit Program, Department of Horticulture Research and Development (DHRD), National Agricultural Research Centre (NARC), Islamabad for facilitating in the arrangement of strawberry cultivar "Chandler".

\section{REFERENCES}

Abdollahi, M., S. Eshghi, E. Tafazol, and N. Moosavi (2012). Effect of paclobutrazol, boric acid and zinc sulfate on vegetative and reproductive growth of strawberry (Fragaria $\times$ Ananassa Duch.) cv. Selva. J. Agri. Sci. Technol. 14: 357363.

Alshaal, T., and H. El-Ramady. (2017). Foliar application: From plant nutrition to biofortification. The Environ, Biodivers \& Soil Secur, 1, 71- 83 .

Arevalo-Gardini, E., M. Canto, J. Alegre, O. Loli, A. Julca, and V. Baligar (2015). Changes in soil physical and chemical properties in long term improved natural and traditional agroforestry management systems of Cacao genotypes in Peruvian Amazon. PLoS One. 10(7):e0132147.

AOAC (1990). Official methods of analysis. Association of analytical chemists. 15th edition, Virginia, Arlington, USA. 12-98 pp.

Asad (1997). Strawberry production and marketing potentials. Advisory leaflet of MFVDP. 30:1-2.

Ayub, M., J. Ullah, A. Muhammad, and A. Zeb (2010). Evaluation of strawberry juice preserved with chemical preservatives at refrigeration temperature. Intl. J. Nutr. Metab. 2:27-32.

Bakshi, P., A. Jasrotia, V.K. Wali, A. Sharma, and M. Akshi (2013). Influence of pre-harvest application of calcium and micro-nutrients on growth, yield, quality and shelf-life of strawberry cv "Chandler". Ind. J. Agric. Sci. 83:831-835.

Bengt, L., and A. Martensson (2003). Organically produced plant food evidence of health benefits. Soil and Plant Sci. 53:3-15.

Bhatt, A., K. Mishra, D.S. Mishra, and C.P. Singh (2012). Foliar application of potassium, calcium, zinc and boron enhanced yield, quality and shelf life of mango. HortFlora Res. Spect. 1(4):300305.

Bowling, B.L. (2000). The berry grower companion. Timber Press Inc., Portland, Oregon, USA.

Chaturvedi, O.P., A.K. Singh, V.K. Tripathi, and A.K. Dixit (2005). Effect of zinc and iron on growth, yield and quality of strawberry cv. "Chandler". Acta. Hort. 696:237-240.

Davis, J.M., S. Douglas, P.V. Nelson, L. Lengnick, and W.J. Sperry (2003). Boron improves growth, yield, quality, and nutrients contents of tomato. J. Am. Soc. Hortic. Sci. 128(3):441-446.

Day, S.C. 2000. Tomato crop in vegetable growing. Agrobios, New Dehli, India, 59-61.

Dale, G.B., and M.L. Krystyna (1998). Boron in plant structure and function. Annu. Rev. Plant Physiol. Plant Mol. Biol. 49:481-500.

Dixit, A., S.S. Shaw, and V. Pal (2013). Effect of micronutrients and plant growth regulators on fruiting of litchi. HortFlora Res. Spect. 2(1):7780.

El-Badawy (2013). Effect of Some Antioxidants and Micronutrients on Growth, Leaf Mineral Content, Yield and Fruit Quality of Canino Apricot Trees. J. Appl. Sci. Res. 9(2):1228.

Fageria, N.K., M.P.B. Filhoa, A. Moreirab, and C.M. Guimaresa (2009). Foliar fertilization of crop plants. J. Plant Nutr. 32: 1044-1064.

Galleta, and Bringhurst (1995). Small fruit culture and nutritional value. The AV publishing west report. 5th edition., USA:357.

Hakkinen, S.H., and A.R. Torronen (2000). Content of flavonols and selected phenolic acids in strawberries and Vaccinium species: influence of cultivar, cultivation site and technique. Food Res. Int. 33(6):517-524.

Hans, Y.S.H. (1992). The guide book of food chemical experiments. Pekin Agricultural University Press, Pekin.

Kerin, V., and M. Berova. (2003). Foliar fertilization in plants. Videnov \& Son, Sofia. Bulgarian. 
Khalid, A.K. (2012). Effect of NP and foliar spray on growth and chemical compositions of some medicinal plants grow in arid regions in Egypt. J. Soil Sci. Plant Nut. 12(3):581-596.

Khan, F.U., N. Khan, and F. Anjum (2016). Farmers perception about yield losses of kinnow (Citrus reticulate) during its harvesting and post harvesting operations: A case study of tehsil Sargodha, Pakistan. J. Rural Dev. Agric. 1(1), 12-19.

Kumar, S.S., K. Pramod, K. Mahesh, S. Saravanan, M.L. Choudhary, and M.C. Sharma (2012). Studies on influence of bio-fertilizers and micronutrients on growth, flowering and yield of strawberry (Fragaria $x$ ananassa Duch) cv. "Chandler". Ann. Hortic. 5:259-264.

May, G.M., and P.M. Pritts (1990). Strawberry nutrition. Adv. Strawberry Res. 9:10-24.

Mohamed, R.A., H.A. Abd El-Aal, and M.G. Abd ElAziz (2011). Effect of Phosphorus, Zinc and their Interaction on vegetative growth characters, yield and fruit quality of Strawberry. J. Hortic. Sci. Ornam. Plants. 3:106-114.

Mohsen, K. (2013). Effects of $\mathrm{Zn}, \mathrm{Fe}$ and their Combination Treatments on the growth and yield of tomato. Bull. Env. Pharmacol. Life Sci. 1:109-114.

Perez, A.G., R. Olias, J. Espada, J.M. Olias, and C. Sanz (1997). Rapid determination of sugars, nonvolatile acids, and ascorbic acid in strawberry and other fruits. J. Agric. Food Chem. 45:3545-3549.

Qureshi, K.M., S. Chughtai, U.S. Qureshi and N.A. Abbasi. (2013). Impact of exogenous application of salt and growth regulators on growth and yield of strawberry. Pakistan J. Bot. 45(4), 11791185.

Rehm, G., and A. Sims (2006). Micronutrients and production of hard red spring wheat. Minnesota Crop News, Univ. Minnesota.
Sarwar, G., H. Schmeisky, N. Hussain, S. Muhammad, M. Ibrahim1, and E. Safdar. (2008). Improvement of soil physical and chemical properties with compost application in ricewheat cropping system. Pakistan J. Bot. 40:275282.

Shiriyan, M., A.H.S. Rad, S. Sayfzadeh, M. Yousefi, and V. Biareh (2013). Influence of plant density and foliar application of iron and zinc on summer savory herb mass. Tech. J. of Eng. Appl. Sci. 3:3346-3349.

Steel, R.G.D., J.H. Torrie, and D. A. Dickey (1997). Principles and procedures of statistics: A biometrical approach. $3^{\text {rd }}$ edition, McGraw Hill Book Company Inc. New York. pp.633.

Singh, M., M. Jamwal, N. Sharma, R. Kumar, and V. Wali (2015). Response of iron and zinc on vegetative and reproductive growth of strawberry (Fragaria $\times$ ananassa Duch.) cv. Chandler. Bangladesh J. Bot. 44(2):337-340.

Ugboh, O., and J.U. Ulebor (2011). Application of integrated soil fertility approach in the improvement of soil fertility in semi-arid ecology. J. Agric. Soc. Res. 11:81-86.

Usha, K., and B. Singh (2002). Effect of macro and micro-nutrient spray on fruit yield and quality of grape (Vitis vinifera) cv. "Perlette". Acta Hort. 594:197-202.

Yadav, M.K., N.L. Patel, B.R. Parmar, Kirtibardhan, and P. Singh (2013). Effect of micronutrients on growth, yield and quality of banana (Musa paradisiaca L.) cv. Grand Nain. Int. J. Agri. Med. Plants Res. 1:1-7.

Yaseen, M. and M. Ahmad (2010). Nutrition management in citrus: effect of multinutrients foliar feeding on the yield of kinnow at different locations. Pakistan J. Bot. 42:1863-1870.

Wang, S.Y., and G.J. Galletta (2002). Compositional change in Colletotrichum (Anthracnose) infected strawberry fruit. Acta Hort. 567: 815-819. 